\title{
Creative Recycling: A Note on Two Grundtvigian Hymns
}

\author{
By Jakob Balling
}

(The following text, slightly revised for the present purpose, formed part of my contribution - entitled $»$ Aspects of Grundtvig's Encounter with Christian Tradition « - to the conference Presenting Grundtvig, in York, England, 24-27. August 2000)

The first of my concluding remarks concerns the use made by Grundtvig the hymnwriter of the ancient church's view of divine service and - inextricably connected to that view - its way of reading the Bible. I find that use instructively illustrated by the paschal hymn »Tag det sorte Kors fra Graven«, »Take the black Cross away from the Grave«. That hymn ${ }^{1}$ - which I have attempted to translate into English prose (see below) - is faithful to tradition in the sense that it communicates the ancient and medieval view of divine service as being the present into which all pasts - and rightly understood the future too - are gathered. The hymn's action takes place now, in a literal and immediate sense. Here and now an Easter congregation is singing. This congregation addresses itself with the invitation to exchange grief for joy, in other words: draw the consequence of the paschal message. It shall do so in a general sense, of course, but in particular it shall do so in regard to the adornment of its graveyard - the piece of earth the congregation has passed through on its way into the church and which it will have to go through again in more senses than one. But that "now" soon ceases to be a "normal« »now». It takes in and incorporates the time of the gospel situation - the past situation in which Mary Magdalene's grief was turned to joy by the Lord's words to her. Mary is consoled now. But in that special "now « the primeval situation too comes into play. In two ways. It happens in the form of the contrast to the ancient call in another garden: "Adam, where art thou? (v.4). But it also happens in the form of the words about the prolonging or continuation of the primeval act of creation, in other words: its character of something that in a sense happens now: $" . .$. creates light in the valley of shadows « (v.4). Salvation, we learn, is a re-creation into which original creation is incorporated or gathered in or fulfilled. But to that something else is added, namely that the future is gathered in too, as testified by two 
striking passages. One: the words in the beginning of v.4: »Burst open, all ye saints' graves! «. Here, a vista is opened towards the general resurrection at the end of days, while at the same time an allusion is placed to something that shall happen to the congregation now: "Now, with the golden dawn, stand up in the name of Jesus, all the Lord's dormant dead " (v.5) (It would, incidentally, be worth our while to let an additional light be shed on this passage by what Grundtvig says in a sermon from 1838, quoted by Thodberg in our recent publication ${ }^{2}$ : $"$...this reality have we found when we found that word of the Lord which will not perish with heaven and earth, when we heard His voice not from afar, but at our side, in our midst, where verily he is baptizing with the Holy Spirit, feeding with the bread that fell from heaven, and pouring wine from the cup of salvation, and now it is our delight to read the Book of the Lord, for now all the graves of the Word burst open, and the holy people, who have been asleep, rise with the Lord and reveal themselves to us, indeed, now all the good words He used to speak come alive to us and are heard anew in the closet and in the congregation to our hope and comfort, to our delight and joy (I). The other passage is the one in v.6 about hurrying to gaze at the place $\mathrm{He}$ prepared for us, "where the depths of heaven are opened on high to eyes of dust « - a passage which likewise combines present and future. - If we survey this intricate confluence, or perhaps better: conflation, of times in the special "now" in which the hymn's action takes place, it will be worth our while to pay attention to two words which so to speak - after the fashion of Augustine's wooden post ${ }^{3}$ - contribute to exercising a carrying and connecting function in the vast network of allusions. One of them is the word "garden". We notice how all the times are gathered together in our garden (the churchyard) which is our present, but also our nearby past in its capacity as the resting place of our departed relatives, as well as our own imminent future. The other word is: "saints' graves". I read that word as referring to three things and times. First: to the "bodies of the saints " which according to Matthew 27:52f rose from their graves at the death of Jesus and "appeared unto many happens to us now when we - in the company of Mary Magdalene - listen to the words of the Lord in the garden of graves. And thirdly to what shall happen on one future morning when the graves just outside the church windows shall burst open.

As hinted at a moment ago: this text is characteristic of the ancient and medieval church's way of conceiving of divine service and - which is the same 
thing, seen from another angle - of its way of reading the Bible: the kind of reading which cannot say Passover in Egypt without saying Easter at Golgotha and vice versa because each of the "Easters" has to be understood in the light of the other. The text is certainly also characteristic of Grundtvig, in the sense that - as I believe - one would search in vain in ancient Christian literature to find anything like an exact parallel to this way of using the traditional ideas about divine service and Scripture. In short: I think we have here an example of creative »recycling «, and I incline to think - without any pretension to proof - that part of the creativity lies, one: in the intimately personal character of the hymn's argument, as testified by the passage in v. 3 where the morning sun has risen from the flood of tears in Mary's eyes - and two: in the natural images in v. 7 where the seasons of winter and spring are brought in to fill the notions of death, hope, and the present and future lot of Christians with concrete life and with a sense of the length and breadth of creation beyond humankind: "Thou earth who in the mild spring wakest up from thy winter's sleep, now, in thy light-green gown - woven hiddenly, like our hope - with thy fragrance of teeming roses, thy voice of soaring larks, thou shalt yearly become a likeness of the lot of thy children's hearts! .

$\mathrm{Be}$ that as it may. In another Grundtvigian hymn - and here comes my second set of remarks - the case for a kind of creativity in the handling of tradition can be proved.

I refer to Grundtvig's version of the Te Deum ${ }^{4}$ - of which my translation into English prose will be found below, together with the Latin text of the original.

My chief interest when dealing with the question of creativity is in the verses 5, 6, and 18-23. Reading them in connection with the Latin text it will be observed, firstly, that a great widening of the historical perspective has taken place: The downcasting of the "proud spirit« in v.6 I understand as an allusion to the fall of Satan before the beginning of world history. The "great divine 'Let there be' " in connection with the present working of the Holy Spirit in v.21, and (in the same context) the reopening of Eden in v.22 represent the same widening of perspective. Secondly: All the verses 18-23 communicate a Spirit theology which goes far beyond anything in the original. - The vistas opened by Grundtvig in the eight verses are more or less completely lacking in the original. That is of interest in itself. But my essential point lies in the fact that everything added by Grundtvig is genuinely patristic and Old European. 
Grundtvig's intimate familiarity with that tradition has been put to use in order to make the text faithful to tradition in a richer and more varied way than it had been beforehand. Here, under the hands of a nineteenth century poet, the $T e$ Deum has been made more fourthcenturyish than it had been in the fourth century. We may, I believe, conclude that tradition is quite a multifarious thing!

Notes

1. Grundtvig's Sangvaerk 1, 2, p. $555 \mathrm{f}$.

2. Christian Thodberg, "Grundtvig's View of the Bible«, in: A.M.Allchin \& al. (eds.), Grundtvig in International Perspective: Studies in the Creativity of Interaction, Århus 2000, p. 130.

3. An allusion to the passage in Augustine's De catechizandis rudibus ch. 20 where the teacher tells the catechumen of how the inner meaning of the striking of the Israelites' door-posts in Egypt with the blood of the paschal lamb is revealed in Christ's bloody cross at Golgotha and in the sign of the cross on the catechumen's forehead »as on a door-post«.

4. Grundtvig's Sang-Vark 1,1, p. $63 \mathrm{ff}$. 
1) Take the black cross away from the grave!

Plant a lily where it stood!

Flowers shall sprout at our feet

with every step in the garden of the dead.

Angels' wings shall be spread on our grave

instead of the broken wanderer's staff,

palm-bird instead of ash-urn,

joyful song instead of hollow sighs!

2) The sun was blackened when He turned pale, He who bought us with His blood.

The grave shone out, darkness sank

when He stood up in glory.

Now ring out, our song of praise, sweetly in the dawn of Easter:

"Jesus Christ is resurrected!

The God-Man lives eternally!«

3) Look at Mary Magdalene!

Just now she wrung her hands in horror, sighed to move stones:

"Where, o where is the Lord now?»

Look: from the flood of tears in her eyes

the mild morning sun has risen!

In the grave where $\mathrm{He}$ has rested, she has found the angel's smile!

4) Burst open, all ye saints' graves!

In the cool dawn the voice of the Lord sounds in the garden of the dead, creates light in the valley of shadows.

The Lord calls, but no longer:

"Sinner, Adam, where art thou?"

Sweetly it sounds - angels are silent -

»Mary, the Saviour is here! 
5) Yea, He is here, the God-Man.

The bands of death are broken!

Surely, He is resurrected,

every word of His is life and spirit every want made good.

Now, with the golden dawn, stand up in the name of Jesus, all the Lord's dormant dead!

6) Rise and see God's finger in the shining garland of witnesses! Hurry on eagle wings to where $\mathrm{He}$ radiantly shines. Hurry in the steps of the Lord to where He prepared a place for us, where the depths of Heaven are opened on high to eyes of dust.

7) Thou earth who in the mild spring wakest up from thy winter's sleep, now, in thy light-green gown - woven hiddenly, like our hope with thy fragrance of teeming roses, thy voice of soaring larks, thou shalt yearly become a likeness of the lot of thy children's hearts! 
1) $O$ great God! We praise thee from our innermost hearts, eternally.

2) Graciously, thou heedest us down here, and thy mercy is eternal.

3) The song of praise from thy redeemed earth shall join in with the choirs of thine angels.

4) Yea, joyfully Adam's race strikes up the song of cherubs and of seraphs: "Holy, Loving, Strong and Wise! From everywhere shalt thou be glorified and praised eternally. Hallelujah!«

5) The heaven in its beauty didst thou create, and the son of dust in thine image.

6) The proud spirit didst thou cast down, the fallen dust raise up.

7) The choirs of apostles and of prophets sing the praises of thy word of grace.

Martyrs bear true witness: »Death for thy sake is bliss!"

8) And all Christendom blesses thee for life and peace.

9) Yea, eternal thanks, gracious Father. Thy Son came to earth with peace.

10) Thy Holy Spirit with voice divine creates life and consolation in the church.

11) Thou King of glory, Saviour dear, be thou welcome and blessed!

12) Thy kingly power didst thou lay down in woman's womb, in stable-room.

13) Our servant's garment didst thou consecrate to heavenly splendour.

14) Our sin didst thou bear, thou brokest our yoke, our punishment didst thou suffer, dying on the cross.

15) From the grave didst thou rise triumphantly, and death's arrogance didst thou quench. 
16) Openly, for all to see, didst thou ascend to Heaven.

Thou keepest thy throne on high in choirs of angels.

17) Thou sittest at the right hand of God, but in thy church thy Spirit lives.

18) O Holy Spirit, dear to our hearts, be thou welcome and blessed!

19) With tongues of fire didst thou descend to tell of God's love.

20) In the breasts of Christians dost thou awaken everything true and good to life and joy. Thou gatherest the people to thy bosom and createst peace in the name of Jesus.

21) In thee we have the seal and pledge that the Word of grace is true, Thou art the great divine "Let there be! « that creates eternal light and life.

22) Hallelujah! Our sorrow is quenched, Eden has been opened for us again.

23) Hallelujah! Great is our joy, God's Spirit dwells in the hut of the dust.

24) Hallelujah! God gladdens us in Heaven eternally. $O$ great God! we praise thee from our innermost hearts eternally.

25) Yea, joyfully Adam's race strikes up the song of cherubs and of seraphs: »Holy, Loving, Strong and Wise! From everywhere shalt thou be glorified and praised eternally. Hallelujah!« 
Hymnus Ambrosianus

Textus in ecclesia receptus

1. Te Deum laudamus, te Dominum confitemur.

2. Te aeternum Patrem omnis terra veneratur.

3. Tibi omnes Angeli, tibi coeli et universae Potestates,

4. Tibi Cherubim et Seraphim incessabili voce proclamant:

5. Sanctus, Sanctus, Sanctus Dominus Deus Sabaoth,

6. Pleni sunt coeli et terra maiestatis gloriae tuae.

7. Te gloriosus Apostolorum chorus,

8. Te Prophetarum laudabilis numerus,

9. Te Martyrum candidatus laudat exercitus.

10. Te per orbem terrarum sancta confitetur Ecclesia,

11. Patrem immensae maiestatis,

12. Venerandum tuum verum et unicum Filium,

13. Sanctum quoque Paraclitum Spiritum.

14. Tu Rex gloriae, Christe,

15. Tu Patris sempiternus es Filius.

16. Tu ad liberandum suscepturus hominem non horruisti Virginis uterum.

17. Tu devicto mortis aculeo aperuisti credentibus regna coelorum.

18. Tu ad dexteram Dei sedes in gloria Patris.

19. Iudex crederis esse venturus.

20. Te ergo quaesumus, famulis tuis subveni, quos pretioso sanguine redemisti.

21. Aeterna fac cum sanctis tuis gloria munerari.

22. Salvum fac populum tuum, Domine, et benedic hereditati tuae.

23. Et rege eos, et extolle illos usque in aeternum.

24. Per singulos dies benedicimus te.

25. Et laudamus nomen tuum in saeculum et in saeculum saeculi.

26. Dignare, Domine, die isto sine peccato nos custodire.

27. Miserere nostri, Domine, miserere nostri.

28. Fiat misericordia tua, Domine, super nos, quemadmodum speravimus in te.

29. In te, Domine, speravi, non confundar in aeternum. 